\title{
An Exploration of Nonresident Student Enrollment and Institutional Finances at Public Universities
}

\author{
Robert Kelchen \\ Department of Educational Leadership and Policy Studies, \\ University of Tennessee, Knoxville
}

\begin{abstract}
Many public universities have sought to increase the number of students they enroll from other states, with the assumption that a larger share of nonresident students increases institutional revenues and prestige. In this paper, I examine the extent to which out-of-state undergraduate student enrollment shares are associated with changes in per-student revenue and expenditure patterns at four-year public universities both as a whole and by selectivity and Carnegie classification. I find that an increase in the percentage of students from out of state is associated with decreases in per-student tuition revenue and is often associated with a decline in per-student expenditures.
\end{abstract}

Keywords: out-of-state students; institutional finances; tuition; higher education policy

* Contact: rkelchen@utk.edu 
Public colleges and universities have traditionally relied on state appropriations as their primary revenue source. But since 1980, the share of public higher education revenues across both two-year and four-year colleges coming from state appropriations has declined from about $73 \%$ to $47 \%$ (author's calculation using data from State Higher Education Executive Officers Association, 2019). Additionally, appropriations are an especially volatile revenue source, as higher education tends to see larger reductions in state funding than most other state budget lines during recessions and larger increases during boom periods (Delaney \& Doyle, 2011, 2018).

Public universities have typically responded to financial challenges by raising tuition and fees, with universities in 30 states now getting more money from tuition than from state appropriations (State Higher Education Executive Officers Association, 2019). Concerns about high tuition prices and rising student debt burdens have made it more difficult for colleges to continue increasing undergraduate tuition on state residents. Fourteen states placed explicit limits on how much colleges could increase in-state tuition or fees (Kelchen \& Pingel, 2018), while other states have implicitly limited tuition or fee increases through pressures placed upon governing board members and college leaders by policymakers (Kelchen, 2017). At the same time, the costs of providing a college education, such as employee benefits and facilities maintenance, have continued to increase faster than the general rate of inflation (Commonfund Institute, 2019).

Public universities that face rising expenditures and stagnant revenues from in-state students and appropriations have turned to other potential revenue sources. One popular source is attempting to increase enrollment of out-of-state or nonresident students (I use the two terms interchangeably throughout the paper) from other states or countries, especially during periods of reduced state appropriations (Bound et al., 2016; Jaquette \& Curs, 2015). The average four-year public university charged out-of-state students approximately $160 \%$ more in tuition and fees than in-state students before taking institutional grant aid into account (Ma et al., 2017), with tuition prices across public research universities converging in recent years (Titus et al., 2015).

As universities have more aggressively pursued students from other states or countries, the percentage of nonresident students at public universities has increased from $9.5 \%$ in 2007-08 to $14.9 \%$ in 2015-16 (author's calculations using data from the National Postsecondary Student Aid Study). The share of out-of-state students is largest at the most selective public universities (17.1\%) and smallest at broad-access public universities (10.2\%). Selective public universities in particular have been able to use nonresident students as a revenue source due to the relative insensitivity of these students to tuition increases (Adkisson \& Peach, 2008; Zhang, 2007). This has created equity concerns, as there is evidence that increased nonresident enrollment at selective public universities was associated with the crowding out of historically underrepresented in-state students (Jaquette et al., 2016).

Prior research suggests that public universities enroll more out-of-state students in an effort to raise additional revenue (e.g., Jaquette \& Curs, 2015), and there is evidence 
that research universities have been able to increase net tuition revenue by increasing the number of international students (Cantwell, 2015; Shen, 2016). However, prior research has found no connection between the nonresident enrollment share and sticker and net prices for in-state students, suggesting that any additional out-of-state tuition revenue does not go to in-state students in the form of additional financial aid or tuition reductions (Kelchen, 2019).

These findings raise important questions about the extent to which universities can raise additional revenue from out-of-state students and whether the resulting funds are spent in ways that could enhance student success. Prior research has found that additional spending on instruction and student services is strongly associated with increases in the graduation rates, while spending on research does not enhance student success (Pike \& Robbins, 2020; Webber \& Ehrenberg, 2010). For these reasons, examining how colleges use any additional revenue is paramount for improving student success and closing longstanding attainment gaps.

In this paper, I delve into the implications of additional out-of-state undergraduate students on revenues and expenditures to examine how colleges appear to be raising and using any additional funds coming from nonresident students. My research questions are the following:

1. To what extent is an increase in nonresident enrollment share associated with an increase in revenue categories?

2. To what extent is an increase in nonresident enrollment share associated with an increase in expenditure categories?

3. Do the above two relationships differ by institutional selectivity and/or research intensity?

\section{Theoretical Framework and Literature Review}

The theoretical framework for my study is resource dependence theory (e.g., Aldrich \& Pfeffer, 1976), which explains that organizations are constantly trying to acquire additional resources and reduce their dependency on any single external source. One clear application of resource dependency theory is the effort to acquire additional tuition dollars through admitting nonresident students. Public universities usually have the ability to set out-of-state tuition rates as desired, and the only limits put on nonresident tuition at the state level typically set floors instead of ceilings on these prices (Armstrong et al., 2017).

Nonresident students can bring two other important resource to a public universityincreased diversity and prestige. For states that serve a racially homogenous population, bringing students from out of state can be a way to expose in-state students to a more diverse student body. This justification is often provided for recruiting international students (NAFSA: Association of International Educators, 2018) and often underlies colleges' participation in programs such as the Posse Scholars program that are 
intentionally designed to recruit underrepresented minority students (Posse Foundation, 2020). However, domestic nonresident students are nearly 10 percentage points more likely to be White than in-state students, meaning that overall effects on diversity may be limited (author's calculation using data from the National Postsecondary Student Aid Study).

Some public universities, particularly flagship state universities and a smaller number of other selective public colleges, are striving to build a national or even international brand (Brewer et al., 2015; O'Meara, 2007) as they pursue academic capitalism (Slaughter \& Leslie, 1997). Geographically-mobile students tend to be higher-achieving than the typical student (Hoxby, 2009; Long, 2004), providing an incentive for public universities to recruit nationally to raise their academic profiles (Harris \& Smith, 2016). For example, public universities recruit National Merit Scholars using large amounts of merit aid and opportunities to access special honors colleges. The University of Oklahoma enrolled more incoming National Merit Scholars than any other university in the country in the 2016-17 academic year (National Merit Scholar Corporation, 2017), with most of those students traditionally coming from other states (Perez-Pena, 2012).

Recruiting a more geographically diverse student body can help increase awareness of a university beyond that state's boundaries, thus potentially improving performance on college rankings such as those from U.S. News \& World Report and Wall Street Journal/ Times Higher Education that include reputation as a ranking criterion (Morse et al., 2018; Times Higher Education, 2018). A substantial body of research has shown a relationship between a selective college's ranking and its future reputation and financial standing (Alter \& Reback, 2014; Bowman \& Bastedo, 2009; Griffith \& Rask, 2007; Luca \& Smith, 2013; Meyer et al., 2017). At public research universities, a higher U.S. News ranking is also associated with both higher nonresident tuition prices (Bastedo \& Bowman, 2011) and higher salaries for college presidents (Yeung et al., 2019).

Colleges may change their spending patterns in an effort to gain the prestige necessary to enroll more nonresident students. One common way to seek prestige is to start additional graduate and professional programs, as regional comprehensive universities feel pressures to act more like research universities (Dey et al., 1997; Gonzales, 2014; O'Meara, 2007). Doctoral programs are particularly valuable, as a certain number of doctoral recipients in a given year can move a university's Carnegie classification into the research university grouping (Brint et al., 2006; Morphew, 2000). While this allows universities to be included in national university rankings (instead of being shunted off to the lesser-known regional university pages), there is evidence that universities shift resources from instruction to research and administrative support to obtain this goal (Ehrenberg, 2012; Iglesias, 2014; Morphew \& Baker, 2004). This means that colleges seeking to become national universities may use the funds they receive from out-ofstate students toward supporting research and administrative functions in an effort to attract more nonresident students in the future. 
The different characteristics of nonresident students may also influence colleges' revenue and expenditure patterns. Since nonresident students tend to have higher family incomes than in-state students, colleges may focus more resources on providing social experiences and amenities to cater to this lucrative group of students (e.g., Armstrong \& Hamilton, 2013; Jacob et al., 2018). There is also some evidence that lower-income students, who are more likely to be state residents, spend more time on academics than the typical student in a potential effort to compensate for their lack of social networks (Goldrick-Rab, 2016). Students with lower test scores (who are more likely to be state residents) see a larger benefit from increased student services expenditures than those with higher test scores, while the same is true based on institutional analyses of the percentage of Pell Grant recipients (Webber, 2012; Webber \& Ehrenberg, 2010).

\section{Sample, Data, and Methods}

To examine the extent to which an increase in the share of nonresident students was associated with changes in public universities' revenue and expenditure patterns, I used data from the 2003-04 through 2015-16 academic years on student enrollment patterns and institutional finances. Details on my sample, data, and methods are in the following sections.

\section{Sample}

The population of interest in this analysis was public four-year universities in the 50 states with first-year undergraduate students, excluding institutions with a Carnegie classification of baccalaureate/associate (mainly community colleges with a small number of bachelor's degree programs). I excluded a small number of special-focus institutions and military academies due to their different pricing and funding structures. I also omitted the six public universities in Nebraska because political control measures were significant predictors of revenues and expenditures in my regression models. Since Nebraska has a unique nonpartisan, unicameral legislature, these important measures were not available for that state. The resulting analytic sample consisted of 526 universities in 49 states.

Because different types of public universities may respond to increases in nonresident enrollment shares in different ways, I divided the sample into two different groups. The first grouping was by institutional selectivity, as measured by Barron's (2009) competitiveness index. I classified 120 universities in the most competitive, very competitive, and highly competitive categories as being more selective, while the other 406 universities with ratings of competitive or below (including unclassified institutions) were classified as being less selective. The second grouping was by Carnegie classification, with the 186 research universities being analyzed separately from the 340 master's and baccalaureate universities. There is some overlap between the two categories, with nearly two-thirds (78) of the selective universities also being research institutions. 


\section{Data}

Data on the percentage of nonresident students (domestic and international) in the incoming first-time undergraduate cohort came from the U.S. Department of Education's Integrated Postsecondary Education Data System (IPEDS). Colleges are required to report information on the residence of students in even-numbered years, while reporting in odd-numbered years is optional. For the roughly $20 \%$ of colleges that did not report in odd-numbered years, I interpolated in even-numbered years by averaging together data from the preceding and following years. For colleges that had data in odd-numbered years, the correlation between their actual reported enrollment and estimated enrollment based on averages was over 0.99. I excluded about one percent of students whose residency status was unknown from the analyses and excluded about one percent of college-by-year observations in which at least five percent of students' residency statuses were unknown. As shown in Table 1, selective universities and research universities enrolled a larger number and share of students from other states in the 2015-16 academic year. But more regionally-focused universities still enrolled nearly one in six students from outside their home state, showing that most public universities do enroll a meaningful proportion of students from other states or countries.

The key revenue and expenditure measures of interest all come from IPEDS. For revenue, I considered three categories that could potentially be tied to the share of out-of-state students: total revenue from all sources, tuition revenue, and revenue from auxiliary enterprises such as housing and food service. While universities receive revenue from other sources, such as research and public service, there is little reason to expect that the share of out-of-state students would affect these other categories. The expenditure categories included total expenditures as well as the subcategories for instruction, research, public service, student services, institutional support, and auxiliary enterprises.

To facilitate comparison across universities, I examined these measures on a per-fulltime equivalent (FTE; undergraduate and graduate students combined) basis. I accounted for a small number of universities (31 in at least one year of the panel) reporting financial data as a system instead of at the institution level (OPEID versus UnitID) by assuming that revenues and expenditures were equally allocated across all campuses on a per-FTE basis, as done by Kelchen (2019). This is likely an imprecise estimate, as noted by Jaquette and Parra (2014), but allows for the largest possible sample size to be used. I also ran models excluding colleges with any parent-child relationships and the results (available upon request) were similar to including the full sample. 
Æ

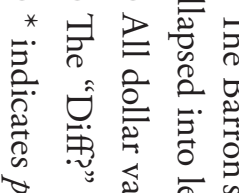

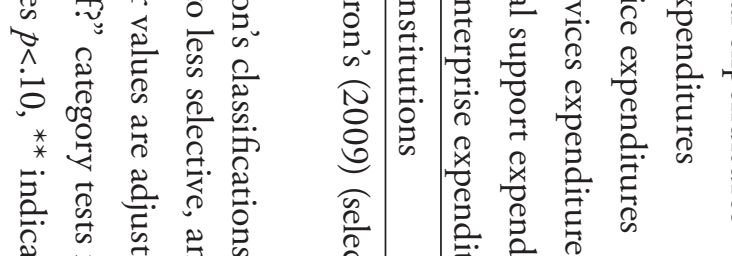

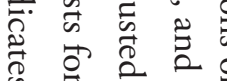

is $\begin{array}{llll}1 & 0 & 0 & 0 \\ 0 & 0 & 0 & 0\end{array}$

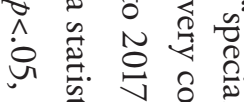

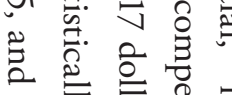

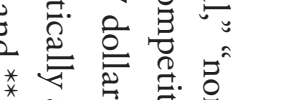

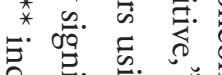

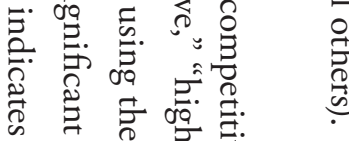

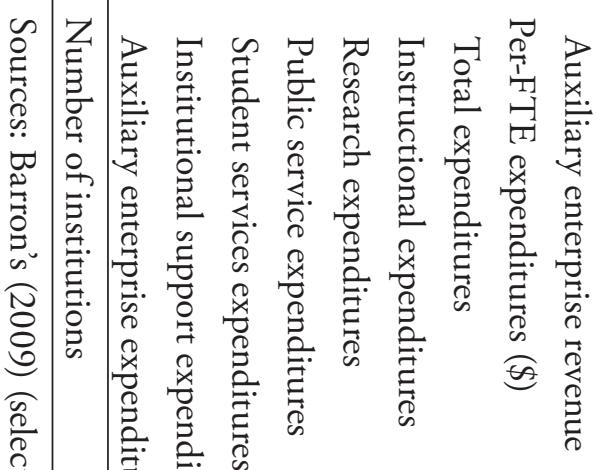

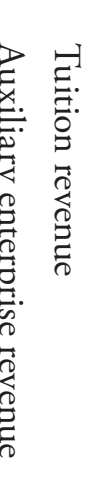

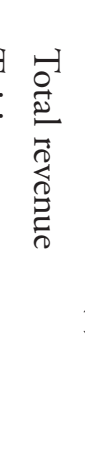

is 2

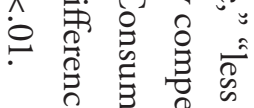

๑)

ट

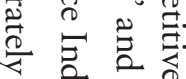

ব)

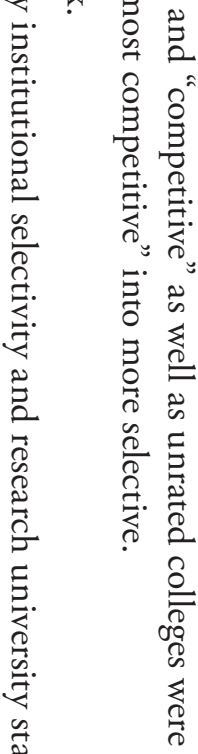

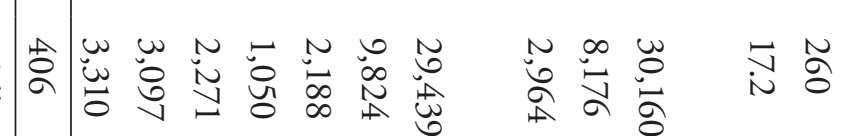

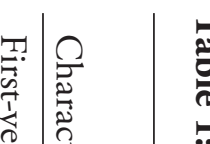

$\frac{\sqrt{0}}{\frac{0}{\sigma}}$

节

总

(2)

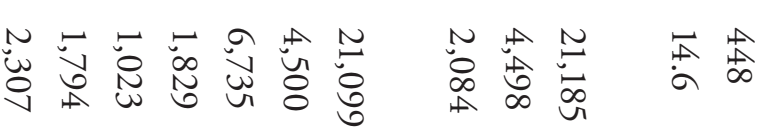

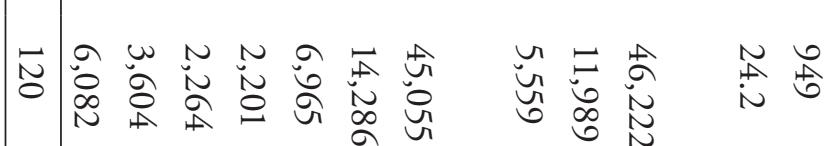

量

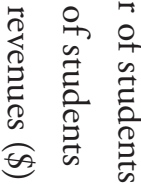

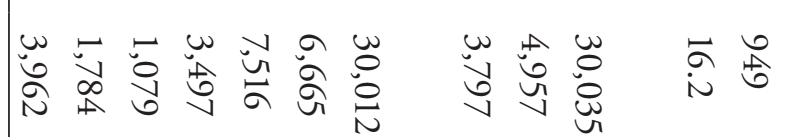

永 
As Table 1 shows, selective and research universities both raise and spend more money in nearly every category than other public universities (with student services being the only exception). Selective and research universities receive roughly $50 \%$ more in both total revenue and tuition revenue than other universities, with the same relationship present for per-student instructional expenditures. Institutional support expenditures were much more similar across the different types of public universities, but selective and research universities still significantly outspent other universities on this general classification of administrative spending.

I also included a set of state-level demographic, economic, and political variables that could affect student demand for public higher education as well as a state's attitude toward supporting public universities; summary statistics can be found for the full sample in Table 2. Since there is a strong relationship between state appropriations and in-state tuition prices (e.g., Delaney \& Doyle, 2011; Webber, 2017) in addition to their influence on total revenues and expenditures, I controlled for per-FTE state and local appropriations using IPEDS data. I also accounted for the percentage of full-time equivalent students enrolled at the undergraduate level to account for the university's relative focus on undergraduate versus graduate education as that could influence certain types of expenditures (such as research). This category was one of the few in this set of covariates that had meaningful differences by institutional selectivity or Carnegie classification.

I included several state economic and demographic conditions as variables to represent in-state families' ability to pay for college. State-level unemployment rates, which are positively correlated with in-state tuition prices (Rizzo \& Ehrenberg, 2004), came from the Bureau of Labor Statistics. Higher state-level poverty rates have been shown to be associated with the replacement of lower-income state residents with out-of-state students (Jaquette et al., 2016). Poverty rate data came from the Bureau of Labor Statistics, while median household income data were from the Census Bureau. To construct an estimate of state grant aid funding effort for traditional-age students, I combined annual survey data from the National Association of State Student Grant and Aid Programs (NASSGAP) on the total amount of grant aid for undergraduates and divided it by the number of young adults between the ages of 18 to 24 (from the Census Bureau). I also used the percentage of state grant aid based on financial need (also from NASSGAP) to account for state support for lower-income resident students. 
Table 2: Description of institutional-level and state-level control variables.

\begin{tabular}{llll}
\hline Characteristic (2015-16) & Mean & St. Dev. & Source \\
\hline More selective institution (pct) & 22.8 & 42.0 & Barron's \\
Carnegie research university (pct) & 35.4 & 47.9 & IPEDS \\
Percent undergraduate enrollment & 88.2 & 8.7 & IPEDS \\
State/local appropriations per FTE $(\$)$ & 7,220 & 4,993 & IPEDS \\
State unemployment rate (pct) & 5.2 & 0.9 & Bureau of Labor Statistics \\
State median income (\$) & 49,625 & 7,460 & Bureau of Labor Statistics \\
Percent residents in poverty (pct) & 13.4 & 2.7 & Census Bureau \\
Pct state grant aid as need-based & 77.1 & 32.1 & NASSGAP \\
State grant aid per 18-24 year old $(\$)$ & 345 & 210 & NASSGAP, Census Bureau \\
Tuition cap at/below CPI (pct) & 23.0 & 42.1 & Author's compilation of data \\
GOP control of state House (pct) & 66.0 & 47.4 & NCSL \\
GOP control of state Senate (pct) & 76.6 & 42.4 & NCSL \\
GOP governor (pct) & 59.0 & 49.2 & NCSL \\
\hline Number of institutions & 526 & & \\
\hline
\end{tabular}

Index to acronyms:

IPEDS=Integrated Postsecondary Education Data System

NASSGAP=National Association of State Student Grant and Aid Programs

NCSL $=$ National Conference of State Legislatures

Public universities may be more inclined to enroll more out-of-state students if they are unable to increase tuition as much as desired on in-state students, and research has shown that colleges' ability to set tuition affects listed in-state tuition and fee prices (Kelchen, 2016; Kim \& Ko, 2015) and overall institutional expenditures (Deming \& Walters, 2017). I measured this flexibility by constructing an institution-by-year dataset based on state policy documents and published media reports, as the available datasets (Armstrong et al., 2017; Deming \& Walters, 2017) were not at the institutional level or present for each year of the panel. In this analysis, I count a university as being subject to a tuition cap if the listed cap was at or below the Consumer Price Index (CPI). This is preferred over counting the presence of a cap because some states had tuition caps of above $10 \%$ in certain years. Approximately $23 \%$ of colleges operated under a tuition cap in the 2015-16 academic year, a percentage that was broadly similar across most years of the dataset. Using a tuition freeze instead of a cap generated substantively similar results, because relatively few states with tuition caps set limits that were at or below the CPI.

My final set of covariates included data from the National Conference of State Legislatures on which political party had control of the state House and Senate as well as the governorship. Research has generally found that states with more Democratic or liberal legislators tend to have higher levels of state appropriations than more Republican or conservative 
states (Archibald \& Feldman, 2006; McLendon et al., 2009; Weerts \& Ronca, 2012), although Tandberg (2010) found the opposite. One study also showed that more liberal states tended to have lower in-state tuition prices at public colleges (Doyle, 2010).

\section{Methods}

To answer my research questions, I used three different panel regression techniques. All of these models used logged, inflation-adjusted (using the Consumer Price Index) revenue and expenditure components as the dependent variables and the percentage of nonresident students as the independent variable of interest. The models also controlled for the institution-level and state-level characteristics in Table 2 along with including year fixed effects and standard errors clustered at the institution level. All financial variables were also logged and inflation-adjusted so the regression coefficients can be interpreted as percentage point changes. In addition to estimating models for all colleges, I estimated models to separately analyze and then compare two different groups of institutions: by Barron's competitiveness rating and by Carnegie classification. To compare the two groups, I added an interaction term between the two groups and the percentage of nonresident enrollment into the regression models after running the regressions separately.

The next analytic decision to consider was when an increase in the share of nonresident students could potentially affect a university's revenues and expenditures. Institutional revenues could be affected as soon as the same year that new nonresident students are enrolled, while the relationship could become stronger in the following several years if the share of nonresident students in the incoming class stabilizes and these students are retained. Expenditures could also increase in the same year that more nonresident students enroll, but a one-year lag is more likely given universities' conservative budgeting practices and the length of time it takes to compile a budget. Nevertheless, I present results using control variables from the same year as well as one, two, and three years before when the financial metrics were measured. As a falsification test, I also included a one-year lead that used control variables from the year after the financial metrics were measured-which should show no relationship unless some underlying trends were not captured in the control variables.

The first regression model that I used was an ordinary least squares (OLS) regression with institutional fixed effects. This is the standard panel regression model, but one potential concern is that past values of a variable can influence current values. This risk of autoregressive $\mathrm{AR}(1)$ processes is quite real since tuition prices and institutional expenditures often increase based on the prior year's values. To address this concern, I estimated two additional models that have been used in other higher education finance studies (e.g., Hillman, 2012; Kelchen, 2019; McLendon et al., 2014).

The next model included the Arellano-Bond (AB) estimator that uses first differences of the variables and two lags of the dependent variable to instrument for potentially endogenous variables in a linear generalized method of moments model (Arellano \& 
Bond, 1991). The final model used the Arellano-Bover/Blundel-Bond (ABBB) estimator that uses lags of both the independent and dependent variables as instruments (Arellano \& Bover, 1995; Blundell \& Bond, 1998). Using these lags means that fewer years of data are available in these models versus standard OLS regressions, but these models are preferred due to how they account for autoregressive processes. I focus on the $\mathrm{AB}$ estimator in these analyses based on prior research and because one more year of data is available for $\mathrm{AB}$ models than $\mathrm{ABBB}$ models. I present the primary results across all three models.

\section{Limitations}

There are two major and three minor limitations of this analysis. The first major limitation is that some of the observed changes in expenditures over time may be due to changes in institutional data reporting practices to IPEDS rather than actual changes in institutional expenditures. Certain expenditure types, such as academic advising, could reasonably be classified under academic support, student services, or instruction, and a change in staff members in the budget or institutional research offices could result in an expenditure type being placed in a different expenditure category (Kolbe $\&$ Kelchen, 2017). These data reporting changes should be idiosyncratic across colleges and thus not affect the general results found in this paper, although they may result in less precise confidence intervals.

The second major limitation is that regional tuition exchanges, which allow some or all students from all or parts of neighboring states to pay a discounted nonresident tuition price, are not directly accounted for in my model. These exchanges are associated with increases in nonresident enrollment (Marsicano \& Kramer, 2018), but a review of regional exchanges' annual reports suggests that membership has been relatively stable during the period of this study. Because of the stability of membership and the fact that not all students in a given state may be eligible for another state's exchange, I do not account for the presence of tuition exchanges and instead allow for baseline nonresident enrollment levels to effectively be differenced out in my analyses.

The first minor limitation is that there is no central data source on the presence or strength of nonresident enrollment caps. While there is no evidence that a large number of public universities operate under caps, the University of California system adopted a cap at the lesser of $18 \%$ of undergraduate enrollment or current levels in 2017 (UC Office of the President, 2017) and the University of Wisconsin-Madison eliminated its cap of $27.5 \%$ on nonresident enrollment (excluding Minnesota) in 2016 (Herzog, 2015). This means there is less context for why some universities may have increased nonresident enrollment over time, as it could be due to the lifting of a previously binding cap or it could be due to a change in institutional strategy. This lack of data should not affect the analyses, but it would be helpful to show the data if they existed. 
Second, there is no way to differentiate the amount of total revenue received from instate versus out-of-state students. IPEDS does not make this distinction, and it appears that very few universities' budget documents delineate the two sources of revenue. For this reason, it is possible that some of any observed relationship between increased nonresident enrollment share and institutional revenues and expenditures could be due to changes affecting the prices paid by in-state students after taking institutional grant aid into account. Finally, not all colleges' fiscal years neatly align with academic years. But, since the timing of fiscal years (such as October to September or July to June) rarely changes for a college, institutional fixed effects largely address this concern.

\section{Results}

I began by examining the association between the percentage of nonresident students and per-FTE university revenues and expenditures for the entire sample of public universities (Table 3). The leftmost columns of Table 3 present a falsification test, comparing the percentage of nonresident students in a given year to revenues and expenditures from the prior year-before these students enrolled. There is no relationship between the share of nonresident students and the prior year's total revenue and expenditures, although there are positive relationships with auxiliary revenues and institutional support expenditures as well as negative relationships with research expenditures (all at $p<.05$ ).

As the columns toward the right of Table 3 show, an increase in the out-of-state student share is associated with a statistically significant decline in total revenue in only one post-enrollment year (two years later). However, a one percent increase in out-of-state enrollment was associated with a decline in tuition revenue of between 0.031 and 0.069 percentage points in the following three years. This suggests that an increase in out-of-state students, which is usually portrayed to be financial boon for universities, did not result in an increase in per-student resources. The negative relationship with per-FTE tuition revenue is particularly surprising, as nonresident students face either similar or higher sticker prices than in-state students.

There was also a decrease in total expenditures as nonresident enrollment increased, with the relationship varying between -0.019 percent and -0.054 percent in the three years following a nonresident enrollment change (significant at $p<.10$ in all three years and at $p<.01$ two years later). The coefficient on instructional spending was consistently negative and significant all but one year after an increase in out-of-state enrollment. Since instructional spending is strongly associated with student success, this finding is a serious concern to students and colleges. The coefficients on research and public service were also negative, but were significant and much larger (as high as -0.36 percent for research and -0.21 percent for public service) two and three years later. Institutional support expenditures were positive and significant at between 0.040 and 0.048 percent at one and three years after out-of-state enrollment increased, while not being significant two years later. 


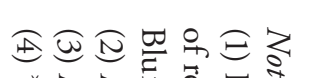

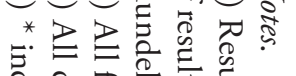

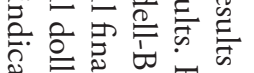

क्षृ

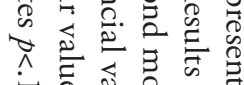

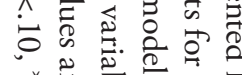

* त

至参

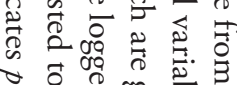

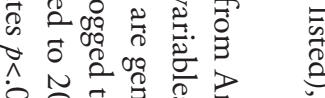

$\dot{\varphi} \begin{aligned} & 0 \\ & 0\end{aligned}$

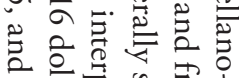

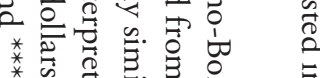

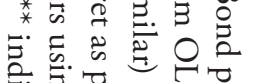

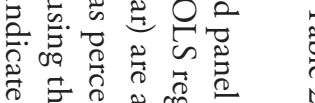

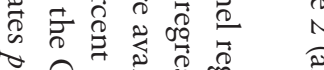

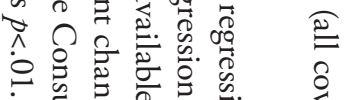

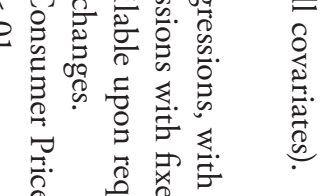

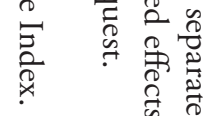

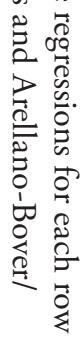
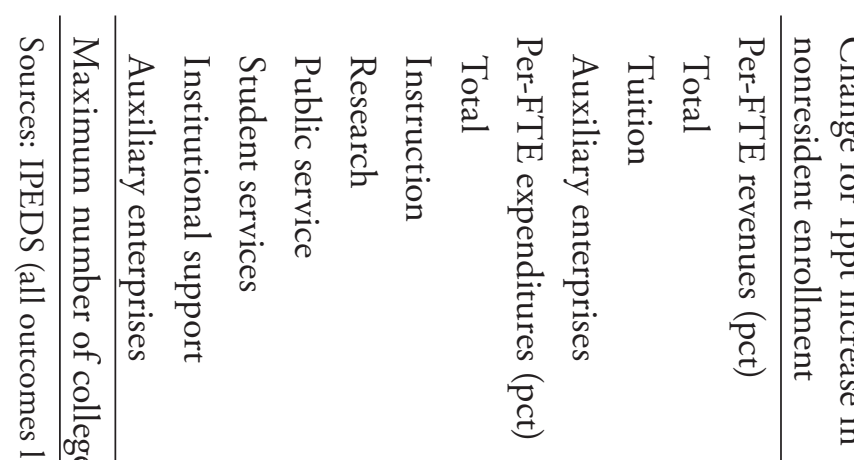

产

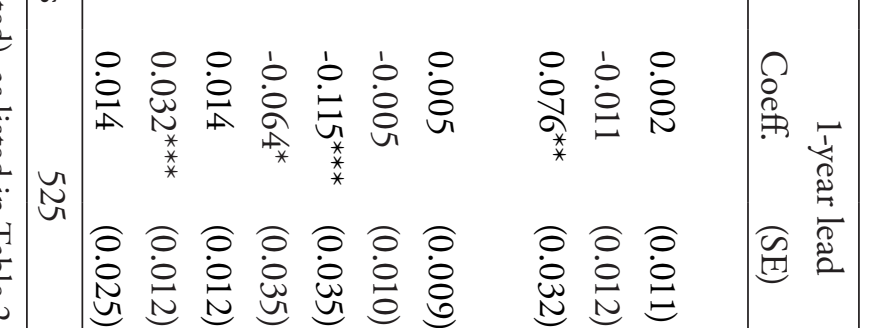

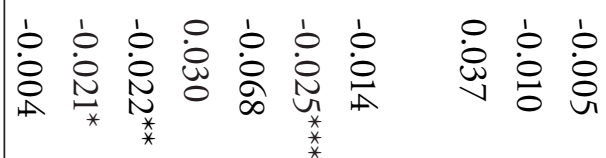

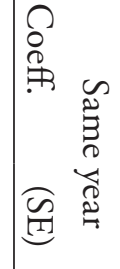

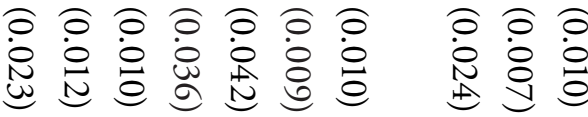

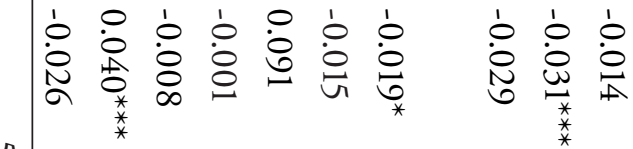

心

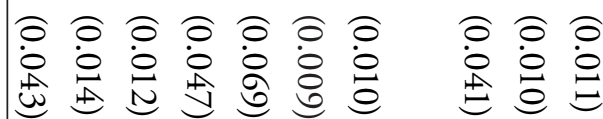

近

吾

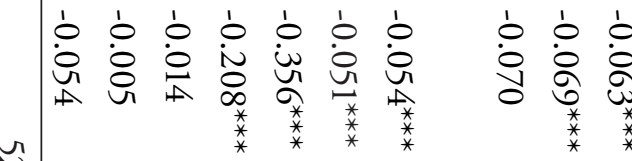

$\underset{\sim}{\widetilde{A}}$

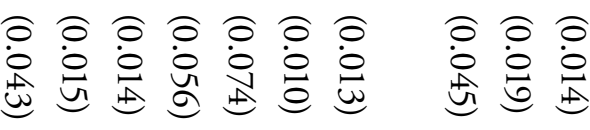

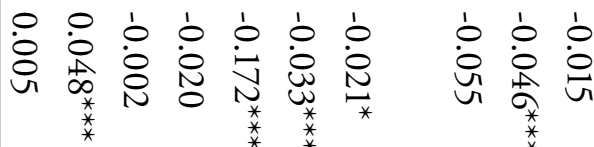

$\widetilde{\simeq}$

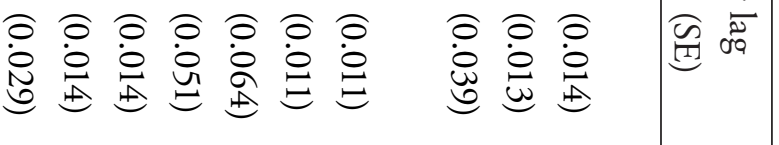


As a robustness check to the preferred $\mathrm{AB}$ model, Appendix 1 contains results for the one-year and three-year lags for OLS regressions with fixed effects as well as the ABBB models. In general, the coefficients for the $\mathrm{AB}$ and $\mathrm{ABBB}$ models are reasonably similar. The coefficients for the OLS models differ slightly from the other two models, but that is to be expected to some extent due to differences in how OLS accounts for the autoregressive nature of the data compared to $\mathrm{AB}$ and $\mathrm{ABBB}$. The general similarities across all three models provide additional confidence in the presented results.

Table 4 contains $\mathrm{AB}$ regression results by institutional selectivity one year and three years later, with the "Diff?" column testing for differences between the two groups using an interaction term in a combined regression model. More selective colleges saw decreases in total revenue of between 0.080 and 0.088 percentage points for each one percent increase in nonresident enrollment, while less selective colleges saw no differences in revenues. This surprising finding suggests that selective colleges are not gaining additional revenue from more out-of-state students who face far higher sticker prices than in-state students. I explore some potential reasons for this finding in the discussion section.

The same story played out for total expenditures, with more selective colleges seeing a decrease in per-student expenditures after enrolling more nonresident students and less selective colleges seeing no changes. The coefficients for instructional and research expenditures were negative one year after an increase in out-of-state students, but were not different from zero three years later. At less selective colleges, institutional support spending increased between 0.044 and 0.058 percentage points while other categories generally were not affected. The regressions testing for differences between more selective and less selective colleges mainly showed that more selective colleges had larger decreases in per-student revenues and expenditures than less selective colleges.

Finally, Table 5 examines whether the implications of enrolling a larger share of nonresident students differ based on whether the university is classified as a research institution by the Carnegie classifications. Unlike the analyses by institutional selectivity, the analyses by Carnegie classifications generally do not find that research-intensive institutions saw large changes in their per-student revenue or expenditure patterns following changes in the number of nonresident students. The same pattern among institutional support was present by Carnegie classification, with non-research universities increasing spending on institutional support as out-of-state enrollment increased. The tests for differences by research university status also showed that research universities had larger reductions in revenue and expenditures than non-research universities, even as most of the comparisons within institutional type were not significant. 
Table 4: Regressions between the percentage of nonresident students and college finances by selectivity.

\begin{tabular}{lccccc}
\hline \multirow{2}{*}{$\begin{array}{l}\text { Change for 1ppt increase in } \\
\text { nonresident enrollment }\end{array}$} & \multicolumn{2}{c}{ Less selective } & \multicolumn{2}{c}{ More selective } & \\
\hline 1-year lag & & $(\mathrm{SE})$ & Coeff. & $(\mathrm{SE})$ & Diff? \\
Per-FTE revenues (pct) & & & & & \\
Total & -0.002 & $(0.011)$ & $-0.088^{* * *}$ & $(0.031)$ & $* * *$ \\
Tuition & -0.015 & $(0.010)$ & $-0.110^{* *}$ & $(0.044)$ & $* * *$ \\
Auxiliary enterprises & -0.014 & $(0.046)$ & -0.071 & $(0.062)$ & $* * *$ \\
Per-FTE expenditures (pct) & & & & & \\
Total & -0.009 & $(0.010)$ & $-0.074^{* * *}$ & $(0.025)$ & $* * *$ \\
Instruction & -0.001 & $(0.009)$ & $-0.087^{* * *}$ & $(0.031)$ & $* * *$ \\
Research & $0.143^{*}$ & $(0.075)$ & $-0.267^{* * *}$ & $(0.101)$ & $* * *$ \\
Public service & 0.006 & $(0.051)$ & -0.093 & $(0.105)$ & \\
Student services & 0.008 & $(0.013)$ & -0.005 & $(0.026)$ & \\
Institutional support & $0.044^{* * *}$ & $(0.014)$ & -0.010 & $(0.031)$ & $* * *$ \\
Auxiliary enterprises & -0.004 & $(0.049)$ & 0.015 & $(0.061)$ & $* * *$ \\
\hline Maximum number of colleges & \multicolumn{7}{c}{405} & & & \\
\hline
\end{tabular}

\section{3-year lag}

Per-FTE revenues (pct)

Total

Tuition

Auxiliary enterprises

Per-FTE expenditures (pct)

\begin{tabular}{lccccc} 
Total & -0.009 & $(0.011)$ & $-0.054^{*}$ & $(0.028)$ & $* * *$ \\
Instruction & -0.014 & $(0.010)$ & -0.010 & $(0.031)$ & $* * *$ \\
Research & -0.104 & $(0.065)$ & -0.229 & $(0.144)$ & $* * *$ \\
Public service & 0.028 & $(0.054)$ & -0.354 & $(0.239)$ & $* *$ \\
Student services & 0.002 & $(0.014)$ & -0.016 & $(0.043)$ & \\
Institutional support & $0.058^{* * *}$ & $(0.015)$ & -0.005 & $(0.029)$ & $* * *$ \\
Auxiliary enterprises & 0.033 & $(0.031)$ & 0.025 & $(0.075)$ & $* * *$ \\
\hline Maximum number of colleges & \multicolumn{5}{c}{115} \\
\hline
\end{tabular}

Sources: IPEDS (all outcomes listed), as listed in Table 2 (all covariates).

Notes.

(1) Results presented here are from Arellano-Bond panel regressions, with separate regressions for each row of results. Results for control variables and from OLS regressions with fixed effects and Arellano-Bover/Blundell-Bond models (which are generally similar) are available upon request.

(2) All financial variables are logged to interpret as percent changes.

(3) All dollar values are adjusted to 2016 dollars using the Consumer Price Index.

(4) ${ }^{*}$ indicates $p<.10,{ }^{* *}$ indicates $p<.05$, and ${ }^{* * *}$ indicates $p<.01$.

(5) "More selective" colleges have a Barron's rating of very competitive, highly competitive, or most competitive.

(6) The "Diff?" column reports the results of an interaction model between selectivity and the percentage of nonresident students. 


\section{Table 5: Regressions between the percentage of nonresident students and college finances by research university status.}

\begin{tabular}{lccccc}
\hline \multirow{2}{*}{$\begin{array}{l}\text { Change for 1ppt increase in } \\
\text { nonresident enrollment }\end{array}$} & Coeff. & $(\mathrm{SE})$ & Coeff. & $(\mathrm{SE})$ & Diff? \\
\hline 1-year lag & & & & & \\
Per-FTE revenues (pct) & & & & & \\
Total & 0.011 & $(0.011)$ & $-0.036^{*}$ & $(0.020)$ & $* * *$ \\
Tuition & -0.015 & $(0.010)$ & -0.018 & $(0.020)$ & $* * *$ \\
Auxiliary enterprises & -0.008 & $(0.053)$ & 0.012 & $(0.035)$ & $* *$ \\
Per-FTE expenditures (pct) & & & & & \\
Total & 0.001 & $(0.010)$ & -0.008 & $(0.019)$ & $* * *$ \\
Instruction & -0.004 & $(0.009)$ & -0.013 & $(0.020)$ & $* * *$ \\
Research & $0.130^{*}$ & $(0.076)$ & 0.081 & $(0.068)$ & $* * *$ \\
Public service & 0.056 & $(0.059)$ & 0.003 & $(0.062)$ & $* * *$ \\
Student services & 0.007 & $(0.014)$ & -0.015 & $(0.025)$ & \\
Institutional support & $0.052^{* * *}$ & $(0.016)$ & -0.015 & $(0.027)$ & $* * *$ \\
Auxiliary enterprises & 0.000 & $(0.058)$ & 0.020 & $(0.039)$ & $* *$ \\
\hline Maximum number of colleges & \multicolumn{3}{c}{339} & & 186 \\
\hline
\end{tabular}

\section{3-year lag}

Per-FTE revenues (pct)

Total

Tuition

Auxiliary enterprises

Per-FTE expenditures (pct)

\begin{tabular}{lccccc} 
Total & 0.000 & $(0.012)$ & -0.013 & $(0.019)$ & $* *$ \\
Instruction & -0.014 & $(0.011)$ & -0.024 & $(0.019)$ & $* * *$ \\
Research & -0.038 & $(0.071)$ & -0.048 & $(0.077)$ & $* * *$ \\
Public service & 0.072 & $(0.063)$ & -0.051 & $(0.079)$ & $* * *$ \\
Student services & -0.002 & $(0.016)$ & -0.014 & $(0.028)$ & \\
Institutional support & $0.068^{* * *}$ & $(0.017)$ & 0.009 & $(0.025)$ & $* * *$ \\
Auxiliary enterprises & 0.057 & $(0.036)$ & 0.020 & $(0.041)$ & $* * *$ \\
\hline Maximum number of colleges & \multicolumn{5}{c}{186} \\
\hline
\end{tabular}

Sources: IPEDS (all outcomes listed), as listed in Table 2 (all covariates).

Notes.

(1) Results presented here are from Arellano-Bond panel regressions, with separate regressions for each row of results. Results for control variables and from OLS regressions with fixed effects and Arellano-Bover/Blundell-Bond models (which are generally similar) are available upon request.

(2) All financial variables are logged to interpret as percent changes.

(3) All dollar values are adjusted to 2016 dollars using the Consumer Price Index.

(4) ${ }^{*}$ indicates $p<.10,{ }^{* *}$ indicates $p<.05$, and ${ }^{* * *}$ indicates $p<.01$.

(5) The "Diff?" column reports the results of an interaction model between selectivity and the percentage of nonresident students. 


\section{Discussion and Implications}

Public universities have increasingly recruited students from other states or countries in an effort to both enhance their prestige and increase tuition revenues in light of rising competition from other colleges and state appropriations that are failing to keep up with increases in educational costs and student enrollments. Yet, although there is evidence that increases in nonresident enrollment squeeze out in-state students from traditionally underrepresented backgrounds (Jaquette et al., 2016) and that a higher share of students from out of state do not lower net prices faced by in-state students (Kelchen, 2019), the question of how nonresident enrollment changes are associated with changes in institutional finances has largely been unexplored.

In this analysis, I examined the association between an increase in the share of students at public universities coming from other states and per-FTE revenues and expenditures. My most surprising finding was that despite the general assumption that nonresident students generate large amounts of additional tuition dollars that can be reinvested into student success initiatives, I found a negative relationship between the share of out-of-state students and the amount of tuition revenue generated. This raises questions about whether many public universities actually generate more net tuition revenue from out-of-state students than in-state students. Notably, most universities were unable to increase spending on student success-related activities as a result of increasing out-of-state student enrollment, meaning that in-state students did not directly benefit from additional out-of-state students.

It is entirely possible that these findings could be a function of most universities failing to generate additional net tuition revenue from out-of-state students. IPEDS data unfortunately do not separate tuition revenue generated from in-state and out-of-state students at this point, making it impossible to get widespread institution-level data on tuition discounting by residency status. The higher education field would benefit from better institution-level data on tuition discounting to help answer important questions about cross-subsidies in public higher education and how funds are used to improve student success.

One potential reason behind nonresident students generating modest amounts of revenue is the presence of regional tuition exchanges. However, it is difficult to obtain comprehensive data on the share of nonresident students attending particular colleges who are actually covered by tuition exchanges given the restrictions and caveats of these programs. Other universities have aggressively discounted tuition to nonresident students in an effort to maintain or increase enrollment. For example, the University of Maine significantly increased nonresident enrollment in the 2016-17 academic year after introducing an advertising campaign informing academically strong out-of-state students that they could enroll at Maine and pay tuition and fees equal to their home state's flagship university. Students under this plan pay slightly more than what Maine students pay, but well below typical nonresident prices (Seltzer, 2017). Youngstown State University in eastern Ohio offers students from selected nearby New York, 
Pennsylvania, and West Virginia counties a tuition rate that is only slightly above in-state rates (Farkas, 2015). Yet, although more recent years of the IPEDS data collections ask colleges to report the number of students paying out-of-state tuition prices, out-of-state rates that are only slightly above the in-state rate are combined with those paying full sticker price.

The findings that per-student expenditures often declined somewhat following an increase in the share of nonresident students were also surprising. This would be a sensible result if universities are simultaneously seeking more students from other states and trying to pare back their budgets in an effort to improve their overall financial health. Given the null findings on tuition and the limited market power of regional public universities, this is a plausible relationship. However, the fact that reductions were often larger at selective public universities and research universities (which tend to have more market power) contradicts this hypothesis to at least some extent. It may still be the case that nearly all public universities are pursuing nonresident students alongside an effort to shore up finances given the uncertainty in state funding during much of the period of study. This question is of particular importance at this time given heightened fiscal concerns that will linger through much of the early 2020 s following the coronavirus pandemic.

In order to more fully understand these results and why the observed relationships occurred, more research needs to be done in addition to addressing the data limitations noted earlier in this section. In particular, interviews with campus leaderships and enrollment management professionals would help shed some light on institutional strategies to recruit more students from outside the state's borders and why a college embarked upon that strategy. It would also be useful to replicate the analyses in this paper with a focus on international students given the prior research that found a relationship between international student enrollment and tuition revenue at public research universities (Cantwell, 2015; Shen, 2016). Finally, interviews with campus leaders would also be helpful to learn more about whether colleges planned to direct any additional revenue from nonresident students to student success initiatives or to other purposes such as research or auxiliary enterprises.

\section{Acknowledgments}

I would like to thank Joseph Fresco and Zhuoyao Liu for their assistance compiling some of the data used in this paper. All errors remain my own. 


\section{References}

Adkisson, R. V., \& Peach, J. T. (2008). Non-resident enrollment and non-resident tuition at land grant colleges and universities. Education Economics, 16(1), 7588. https://doi.org/10.1080/09645290701563156

Aldrich, H. E., \& Pfeffer, J. (1976). Environments of organizations. Annual Review of Sociology, 2, 79-105. https://doi.org/10.1146/annurev.so.02.080176.000455

Alter, M., \& Reback, R. (2014). True for your school? How changing reputations alter demand for selective U.S. colleges. Educational Evaluation and Policy Analysis, 36(3), 346-370. https://doi.org/10.3102\%2F0162373713517934

Archibald, R. B., \& Feldman, D. H. (2006). State higher education spending and the tax revolt. The Journal of Higher Education, 77(4), 618-644. https://doi.org/10.10 80/00221546.2006.11772309

Arellano, M., \& Bond, S. (1991). Some tests of specification for panel data: Monte Carlo evidence and an application to employment equations. The Review of Economic Studies, 58(2), 277-297. https://doi.org/10.2307/2297968

Arellano, M., \& Bover, O. (1995). Another look at the instrumental variable estimation of error-components models. Journal of Econometrics, 68(1), 29-51. https:// doi.org/10.1016/0304-4076(94)01642-D

Armstrong, E. A., \& Hamilton, L. T. (2013). Paying for the party: How college maintains inequality. Harvard University Press.

Armstrong, J., Carlson, A., \& Laderman, S. (2017). The state imperative: Aligning tuition policies with strategies for affordability. State tuition, fees, and financial assistance policies 2017. State Higher Education Executive Officers. https:// sheeo.org/wp-content/uploads/2019/02/State_Tuition_Fees_Financial_Assistance_2017.pdf

Barron's Educational Series, Inc. (2009). Barron's profiles of American colleges: Descriptions of the colleges. Barron's Educational Series, Inc.

Bastedo, M. N., \& Bowman, N. A. (2011). College rankings as an interorganizational dependency: Establishing the foundation for strategic and institutional accounts. Research in Higher Education, 52(1), 3-23. https://doi.org/10.1007/ s11162-010-9185-0

Blundell, R., \& Bond, S. (1998). Initial conditions and moment restrictions in dynamic panel data models. Journal of Econometrics, 87(1), 115-143. https://doi. org/10.1016/S0304-4076(98)00009-8

Bound, J., Braga, B., Khanna, G., \& Turner, S. (2016). A passage to America: University funding and international students. National Bureau of Economic Research Working Paper 22981. https://doi.org/10.3386/w22981 
Bowman, N. A., \& Bastedo, M. N. (2009). Getting on the front page: Organizational reputation, status signals, and the impact of U.S. News and World Report on student decisions. Research in Higher Education, 50(5), 415-436. https://doi. org/10.1007/s11162-009-9129-8

Brewer, D. J., Gates, S. M., \& Goldman, C. A. (2002). In pursuit of prestige: Strategy and competition in U.S. higher education. Transaction Publishers.

Brint, S., Riddle, M., \& Hanneman, R. A. (2006). Reference sets, identities, and aspirations in a complex organizational field: The case of American four-year colleges and universities. Sociology of Education, 79(3), 229-252. https://doi.org/1 $0.1177 \% 2 \mathrm{~F} 003804070607900303$

Cantwell, B. (2015). Are international students cash cows? Examining the relationship between new international undergraduate enrollments and institutional revenue and public colleges and universities in the US. Journal of International Students, 5(4), 512-525. http://dx.doi.org/10.32674/jis.v5i4.412

Commonfund Institute. (2019). Commonfund higher education price index. https:// www.commonfund.org/higher-education-price-index

Delaney, J. A., \& Doyle, W. R. (2011). State spending on higher education: Testing the balance wheel over time. Journal of Education Finance, 36(4), 343-368. https://www.jstor.org/stable/23018116

Delaney, J. A., \& Doyle, W. R. (2018). Patterns and volatility in state funding for higher education, 1951-2006. Teachers College Record, 120(6), 1-42.

Deming, D. J., \& Walters, C. R. (2017). The impact of price caps and spending cuts on U.S. postsecondary attainment. National Bureau of Economic Research Working Paper 23736. https://doi.org/10.3386/w23736

Dey, E. L., Milem, J. F., \& Berger, J. B. (1997). Changing patterns of publication productivity: Accumulative advantage or institutional isomorphism? Sociology of Education, 70(4), 308-323. https://doi.org/10.2307/2673269

Doyle, W. R. (2010). Does merit-based aid "crowd out" need-based aid? Research in Higher Education, 51(5), 397-415. https://doi.org/10.1007/s11162-010-9166-3

Ehrenberg, R. G. (2012). American higher education in transition. Journal of Economic Perspectives, 26(1), 193-216. https://doi.org/10.1257/jep.26.1.193

Farkas, K. (2015, June 17). Youngstown State University will freeze tuition for undergraduate students. Cleveland Plain Dealer. https://www.cleveland.com/ metro/index.ssf/2015/06/youngstown_state_university_wi.html

Goldrick-Rab, S. (2016). Paying the price: College costs, financial aid, and the betrayal of the American dream. University of Chicago Press.

Gonzales, L. D. (2014). Framing faculty agency inside striving universities: An application of Bourdieu's theory of practice. The Journal of Higher Education, 85(2), 193-218. https://doi.org/10.1080/00221546.2014.11777324 
Griffith, A., \& Rask, K. (2007). The influence of the US News and World Report collegiate rankings on the matriculation decision of high-ability students, 19952004. Economics of Education Review, 26(2), 244-255. https://doi.org/10.1016/j. econedurev.2005.11.002

Harris, M. S., \& Smith, M. (2016). Recruiting nonresident students and the privatization of public universities. College and University, 91(2), 2-9.

Hazelkorn, E. (2015). Rankings and the reshaping of higher education: The battle for world-class excellence. Palgrave Macmillan.

Herzog, K. (2015, October 8). Regents panel backs lifting of UW-Madison nonresident enrollment cap. Milwaukee Journal-Sentinel. http://archive.jsonline.com/ news/education/regents-panel-backs-lifting-of-uw-madison-nonresident-enrollment-cap-b99592678z1-331337171.html/

Hillman, N. W. (2012). Tuition discounting for revenue management. Research in Higher Education, 53(3), 263-281. https://doi.org/10.1007/s11162-011-9233-4

Hoxby, C. M. (2009). The changing selectivity of American colleges. Journal of Economic Perspectives, 23(4), 95-118. https://doi.org/10.1257/jep.23.4.95

Iglesias, K. W. (2014). The price of prestige: A study of the impact of striving behavior on the expenditure patterns of American colleges and universities [Unpublished doctoral dissertation]. Seton Hall University.

Jacob, B., McCall, B., \& Stange, K. (2018). College as country club: Do colleges cater for students' preferences for consumption? Journal of Labor Economics, 36(2), 309-348. https://doi.org/10.1086/694654

Jaquette, O., \& Curs, B. R. (2015). Creating the out-of-state university: Do public universities increase nonresident freshman enrollment in response to declining state appropriations? Research in Higher Education, 56(6), 535-565. https:/doi. org/10.1007/s11162-015-9362-2

Jaquette, O., Curs, B. R., \& Posselt, J. R. (2016). Tuition rich, mission poor: Nonresident enrollment and the changing proportions of low-income and underrepresented minority students at public research universities. The Journal of Higher Education, 87(5), 635-673. https://doi.org/10.1080/00221546.2016.11777417

Jaquette, O., \& Parra, E. E. (2014). Using IPEDS for panel analyses: Core concepts, data challenges, and empirical applications. In M. B. Paulsen (Ed.), Higher education: Handbook of theory and research (Vol. 29, pp. 467-533). Springer.

Kelchen, R. (2016). An analysis of student fees: The roles of states and institutions. The Review of Higher Education, 39(4), 597-619. https://doi.org/10.1353/ rhe.2016.0027

Kelchen, R. (2017). Tuition control policies: A challenging approach to college affordability. Midwestern Higher Education Compact. https://www.mhec.org/sites/ default/files/resources/mhec_affordability_series3_20170824.pdf

Kelchen, R. (2019). Do nonresident students affect prices for in-state students at public colleges? Teachers College Record, 121(1). 
Kelchen, R., \& Pingel, S. (2018). Postsecondary tuition capping and freezing. Education Commission of the States. https://www.ecs.org/wp-content/uploads/Postsecondary-Tuition-Capping-and-Freezing.pdf

Kim, M. M., \& Ko, J. (2015). The impacts of state control policies on college tuition increase. Educational Policy, 29(5), 815-838. https://doi. org/10.1177\%2F0895904813518100

Kolbe, T., \& Kelchen, R. (2017). Identifying new metrics using IPEDS finance data. National Postsecondary Education Cooperative. https:/nces.ed.gov/ipeds/pdf/ npec/data/NPEC_Paper_New_IPEDS_Finance_Metrics_2017.pdf

Long, B. T. (2004). How have college decisions changed over time? An application of the conditional logistic choice model. Journal of Econometrics, 121, 271-296. https://doi.org/10.1016/j.jeconom.2003.10.004

Luca, M., \& Smith, J. (2013). Salience in quality disclosure: Evidence from the U.S. News college rankings. Journal of Economics \& Management Strategy, 22(1), 58-77. https://doi.org/10.1111/jems.12003

Ma, J., Baum, S., Pender, M., \& Welch, M. (2017). Trends in college pricing. The College Board. https://research.collegeboard.org/trends/college-pricing

Marsicano, C. R., \& Kramer, J. W. (2018) Cross-border student migration and regional tuition exchange compacts [Paper presentation]. American Educational Research Association, New York.

McLendon, M. K., Hearn, J. C., \& Mokher, C. G. (2009). Partisans, professionals, and power: The role of political factors in state higher education funding. The Journal of Higher Education, 80(6), 686-713. https://doi.org/10.1353/jhe.0.0075

McLendon, M. K., Tandberg, D. A., \& Hillman, N. W. (2014). Financing college opportunity: Factors influencing state spending on student financial aid and campus appropriations, 1990 through 2010. The ANNALS of the American Academy of Political and Social Science, 655(1), 143-162. https://doi. org/10.1177\%2F0002716214540849

Meyer, A. G., Hanson, A. R., \& Hickman, D. C. (2017). Perceptions of institutional quality: Evidence of limited attention to higher education rankings. Journal of Economic Behavior \& Organization, 142, 241-258. https://doi.org/10.1016/j. jebo.2017.07.036

Morphew, C. C. (2000). Institutional diversity, program acquisition, and faculty members: Examining academic drift at a new level. Higher Education Policy, 13, 55-77. https://doi.org/10.1016/S0952-8733(99)00028-8

Morphew, C. C., \& Baker, B. D. (2004). The cost of prestige: Do new research I universities incur higher administrative costs? Review of Higher Education, 27(3), 365-384. https://doi.org/10.1353/rhe.2004.0005

Morse, R., Brooks, E., \& Mason, M. (2018, September 9). How U.S. News calculated the 2019 best colleges rankings. U.S. News \& World 
Report. https://www.usnews.com/education/best-colleges/articles/

how-us-news-calculated-the-rankings

NAFSA: Association of International Educators. (2018). NAFSA

2018 worldview global workforce development roundtable.

https://www.nafsa.org/about/about-international-education/

nafsa-2018-worldview-global-workforce-development-roundtable

National Merit Scholarship Corporation. (2017). 2016-17 annual report. https://www. nationalmerit.org/s/1758/start.aspx?sid=1758\&gid $=2$

O'Meara, K. (2007). Striving for what? Exploring the pursuit of prestige. In J. C. Smart (Ed.), Higher education: Handbook of theory and research (Vol. XXII, pp. 121-179). Springer.

Perez-Pena, R. (2012, December 11). Courting merit scholars opens door to questions. The New York Times. http://www.nytimes.com/2012/12/12/education/somequestion-merit-aid-at-university-of-oklahoma.html

Pike, G. R., \& Robbins, K. R. (2020). Using panel data to identify the effects of institutional characteristics, cohort characteristics, and institutional actions on graduation rates. Research in Higher Education, 61, 485-509. https:/doi. org/10.1007/s11162-019-09567-7

Posse Foundation. (2020). College \& university partners. https://www.possefoundation.org/supporting-scholars/college-university-partners

Rizzo, M., \& Ehrenberg, R. G. (2004). Resident and nonresident tuition and enrollment at flagship state universities. In C. M. Hoxby (Ed.), College choices: The economics of where to go, when to go, and how to pay for it (pp. 303-349). University of Chicago Press.

Seltzer, R. (2017, May 11). Tuition matching, take 2. Inside Higher Ed. https://www.insidehighered.com/news/2017/05/11/ university-maine-sees-slower-growth-second-year-flagship-match-program

Shen, Y. (2016). The impacts of the influx of new foreign undergraduate students on U.S. higher education. Working paper. https://economics.nd.edu/assets/212112/ ying_foreign_students.pdf

Slaughter, S., \& Leslie, L. L. (1997). Academic capitalism: Politics, policies, and the entrepreneurial university. Johns Hopkins University Press.

State Higher Education Executive Officers. (2019). State higher education finance: FY 2018. https://sheeo.org/wp-content/uploads/2019/04/SHEEO_SHEF_FY18_ Report.pdf

Tandberg, D. A. (2010). Politics, interest groups and state funding of public higher education. Research in Higher Education, 51(5), 416-450. https://doi.org/10.1007/ s11162-010-9164-5

Times Higher Education. (2018, August 31). Wall Street Journal/Times Higher Education college rankings 2019 methodology. https:/www.timeshighereducation.com/ wall-street-journal-times-higher-education-college-rankings-2019-methodology 
Titus, M. A., Vamosiu, A., \& Gupta, A. (2015). Conditional converge of nonresident tuition rates at public research universities: A panel data analysis. Higher Education, 70(6), 923-940. https://doi.org/10.1007/s10734-015-9883-9

UC Office of the President. (2017, May 18). UC Board of Regents approves policy on nonresident student enrollment. https://www.universityofcalifornia.edu/ press-room/uc-board-regents-approves-policy-nonresident-student-enrollment

Webber, D. A. (2012). Expenditures and postsecondary graduation: An investigation using individual-level data from the state of Ohio. Economics of Education Review, 31(5), 615-618. https://doi.org/10.1016/j.econedurev.2012.02.003

Webber, D. A. (2017). State divestment and tuition at public institutions. Economics of Education Review, 60, 1-4. https://doi.org/10.1016/j.econedurev.2017.07.007

Webber, D. A., \& Ehrenberg, R. G. (2010). Do expenditures other than instructional expenditures affect graduation and persistence rates in American higher education? Economics of Education Review, 29(6), 947-958. https://doi.org/10.1016/j. econedurev.2010.04.006

Weerts, D. J., \& Ronca, J. M. (2012). Understanding differences in state support for higher education across states, sectors, and institutions: A longitudinal study. The Journal of Higher Education, 83(2), 155-185. https://doi.org/10.1080/002215 46.2012.11777238

Yeung, R., Gigliotti, P., \& Nguyen-Hoang, P. (2019). The impact of U.S. News college rankings on the compensation of college and university presidents. Research in Higher Education, 60, 1-17. https://doi.org/10.1007/s11162-018-9501-7

Zhang, L. (2007). Nonresident enrollment demand in public higher education: An analysis at national, state, and institutional levels. The Review of Higher Education, 31(1), 1-25. https://doi.org/10.1353/rhe.2007.0057 


\section{Appendix 1: Results across three different regression models.}

\begin{tabular}{|c|c|c|c|c|c|c|}
\hline \multirow{2}{*}{$\begin{array}{l}\text { Change for 1ppt increase in } \\
\text { nonresident enrollment } \\
\text { (1-year lag) }\end{array}$} & \multicolumn{2}{|c|}{ Regression w/FEs } & \multicolumn{2}{|c|}{ Arellano-Bond } & \multicolumn{2}{|c|}{$\begin{array}{c}\text { Arellano-Boyer/ } \\
\text { Blundell-Bond }\end{array}$} \\
\hline & Coeff. & $(\mathrm{SE})$ & Coeff. & $(\mathrm{SE})$ & Coeff. & $(\mathrm{SE})$ \\
\hline \multicolumn{7}{|l|}{ 1-year lag } \\
\hline \multicolumn{7}{|l|}{ Per-FTE revenues (pct) } \\
\hline Total & -0.002 & $(0.008)$ & -0.014 & $(0.011)$ & -0.005 & $(0.013)$ \\
\hline Tuition & 0.008 & $(0.007)$ & $-0.031^{* * *}$ & $(0.010)$ & $-0.025^{* * *}$ & $(0.010)$ \\
\hline Auxiliary enterprises & $0.077^{* * *}$ & $(0.022)$ & -0.029 & $(0.041)$ & $0.014^{*}$ & $(0.007)$ \\
\hline \multicolumn{7}{|l|}{ Per-FTE expenditures (pct) } \\
\hline Total & -0.005 & $(0.007)$ & $-0.019^{*}$ & $(0.010)$ & -0.005 & $(0.011)$ \\
\hline Instruction & $-0.023^{* * *}$ & $(0.006)$ & -0.015 & $(0.009)$ & -0.005 & $(0.010)$ \\
\hline Research & $-0.072^{*}$ & $(0.040)$ & 0.091 & $(0.069)$ & $0.112^{*}$ & $(0.062)$ \\
\hline Public service & -0.039 & $(0.031)$ & -0.001 & $(0.047)$ & 0.086 & $(0.069)$ \\
\hline Student services & -0.011 & $(0.007)$ & -0.008 & $(0.012)$ & 0.006 & $(0.011)$ \\
\hline Institutional support & $0.027^{* * *}$ & $(0.009)$ & $0.040^{* * *}$ & $(0.014)$ & 0.016 & $(0.013)$ \\
\hline Auxiliary enterprises & 0.017 & $(0.019)$ & -0.026 & $(0.043)$ & 0.015 & $(0.055)$ \\
\hline Maximum number of colleges & \multicolumn{2}{|c|}{525} & \multicolumn{2}{|c|}{525} & \multicolumn{2}{|c|}{525} \\
\hline
\end{tabular}

\section{3-year lag}

Per-FTE revenues (pct)

Total

Tuition

Auxiliary enterprises

$$
\begin{array}{cccccc}
-0.036^{* * *} & (0.010) & -0.015 & (0.014) & -0.015 & (0.014) \\
-0.026^{* * *} & (0.009) & -0.046^{* * *} & (0.013) & -0.026 & (0.020) \\
0.014 & (0.027) & -0.055 & (0.039) & 0.001 & (0.040)
\end{array}
$$

Per-FTE expenditures (pct)

Total

\begin{tabular}{lcccccc} 
Total & $-0.034^{* * *}$ & $(0.010)$ & $-0.021^{*}$ & $(0.011)$ & $-0.023^{* *}$ & $(0.011)$ \\
Instruction & $-0.036^{* * *}$ & $(0.008)$ & $-0.033^{* * *}$ & $(0.011)$ & $-0.036^{* * *}$ & $(0.012)$ \\
Research & $-0.232^{* * *}$ & $(0.055)$ & $-0.172^{* * *}$ & $(0.064)$ & $-0.149^{* * *}$ & $(0.056)$ \\
Public service & $-0.154^{* * *}$ & $(0.042)$ & -0.020 & $(0.051)$ & -0.015 & $(0.055)$ \\
Student services & 0.009 & $(0.009)$ & -0.002 & $(0.014)$ & 0.003 & $(0.013)$ \\
Institutional support & $0.038^{* * *}$ & $(0.011)$ & $0.048^{* * *}$ & $(0.014)$ & 0.014 & $(0.014)$ \\
\hline Maximum number of colleges & \multicolumn{5}{c}{524} & \multicolumn{5}{c}{524}
\end{tabular}

Sources: IPEDS (all outcomes listed), as listed in Table 2 (all covariates).

Notes.

(1) Each row reflects a separate regression. Coefficients for control variables are not shown, but are available upon request from the author.

(2) All financial variables are logged to interpret as percent changes.

(3) All dollar values are adjusted to 2016 dollars using the Consumer Price Index.

(4) * indicates $p<.10, * *$ indicates $p<.05$, and $* * *$ indicates $p<.01$. 